\title{
Trace element geochemistry during metamorphic dehydration: A case study from the Xingzi Group of Lushan, southeast China
}

\author{
HONG-FENG TANG and CONG-QIANG LIU* \\ Laboratory for Study of the Earth's Interior and Geofluids, Institute of Geochemistry, \\ Chinese Academy of Sciences, Guiyang 550002, China
}

(Received October 1, 2001; Accepted May 28, 2002)

\begin{abstract}
The Xingzi Group, exposed in Lushan, southeast China, is the oldest basement in the Late Proterozoic Jiangnan orogen and composed mainly of metamorphosed psammites and pelitic schists with the grade of amphibolite facies. Eight quartz and felsic veins from two locations in this group have been chosen to investigate trace element behaviour during metamorphic dehydration. One location is at Xixiansi, where the wallrocks are completely metamorphosed psammites, and the other at Huangyansi, where the wallrocks are mainly pelitic schists.

According to their field and petrologic characteristics, all the veins studied from the two locations are synmetamorphic in origin and were deposited by metamorphic fluids derived from their wallrocks. This is further indicated by the similar oxygen isotopic compositions of mineral separates between the veins and their immediate wallrocks. The estimated mean $\delta^{18} \mathrm{O}$ values of the fluids equilibrated with minerals are $11.2 \%$ at Xixiansi and $10.2 \%$ at Huangyansi, supporting no pervasive fluid infiltration on a relatively large scale across whole the Xingzi Group during metamorphism. The much different $\mathrm{Nb} / \mathrm{Ta}, \mathrm{Zr} / \mathrm{Hf}$ and $\mathrm{Pb} / \mathrm{Nd}$ ratios in the veins from those in their wallrocks as well as the REE tetrad effects in the veins at Huangyansi indicate fractionation of the REEs and several geochemical pairs (Nb-Ta, $\mathrm{Zr}-\mathrm{Hf}$, and $\mathrm{Pb}-\mathrm{Nd}$ ) during metamorphic dehydration. In addition, the large ion lithophile elements (LILEs) show a different behaviour during this process. The ratios of $\mathrm{La} / \mathrm{Ba}, \mathrm{Sr} / \mathrm{Nd}$ and $\mathrm{Th} / \mathrm{Hf}$ are similar in all veins and wallrocks. $\mathrm{Rb} / \mathrm{Ba}, \mathrm{Ba} / \mathrm{Nb}, \mathrm{La} / \mathrm{Nb}$, and $\mathrm{La} / \mathrm{Yb}$ ratios are also similar in the quartz veins and wallrocks, but vary significantly in the felsic veins, suggesting their fractionation in the felsic veins. The various REE abundances in the veins confirm that the REEs in sedimentary rocks can obviously be mobilized during regional metamorphism of amphibolite facies. Based on differences in trace element characteristics of the veins between Xixiansi and Huangyansi, we conclude that the mineralogical compositions of the protoliths most likely play an important role in controlling the chemical compositions of the fluid, and in turn, controlling REE and other trace element behaviour during metamorphic dehydration.
\end{abstract}

\section{INTRODUCTION}

Various veins, such as feldspar-bearing veins (Yardley, 1975), distinctive metamorphic mineralbearing veins (Yardley, 1986; Bebout and Barton, 1989; Cesare, 1994; Putlitz et al., 2002; Becker et al., 1999) and carbonate veins (Cartwritght et al., 1994), occur in metamorphic terrains worldwide. Among these, quartz veins are most abundant (Yardley and Bottrell, 1992; Ague, 1994;
Smith and Yardley, 1999). Such veins are important manifestations of fluids related to metamorphism and enable the study of the origins of metamorphic fluids and the behaviour of element during metamorphism. Previous studies on metamorphic veins mainly focused on their mineral, major element and oxygen isotopic compositions (Yardley, 1975; Yardley and Bottrell, 1992; Ague, 1994; van Haren et al., 1996), and different hypotheses have been advanced to account for their

*Corresponding author (e-mail: liucq@mimi.cnc.ac.cn) 
genesis (van Haren et al., 1996). Two contrasting transport mechanisms, local diffusion and regionally channelized flow, have been suggested for vein-forming metamorphic fluids.

Fluid is a potentially important agent of mass transfer in metamorphism. The mass transfer is indicated by the mobility and migration of some elements, including those soluble in a fluid phase, such as K, Na, Ba, Rb (Ferry, 1983; Bebout and Barton, 1989), and even some less soluble elements, such as Si and Al (Anderson and Burnham, 1983; Ague, 1991). The extent of the mobility of the rare earth elements (REE) during metamorphism has been a controversial issue for several decades, because of their rather low solubility in the fluid phase (Grauch, 1989; and references therein). Although experimental and theoretical studies on the stability of inorganic complex species of the REE (see review of Wood, 1990; Haas et al., 1995) provide a basis for understanding whether REEs are mobile or immobile, more geological examples are needed to examine the mechanism(s) of the mobility or reason(s) for the immobility. Trace elements probably fractionate during metamorphic dehydration due to varying degrees of removal by fluids (Bebout et al., 1999; Becker et al., 1999). However, previous studies mainly pertain to subduction metamorphism of basalts, and few especially deal with REEs.

In this paper we investigate the trace element and oxygen isotopic compositions of synmetamorphic veins and their wallrocks in the Xingzi Group metasedimentary rocks of Lushan, southeast China in order to provide data that increases our understanding of trace element (especially REE) behaviour during metamorphic dehydration.

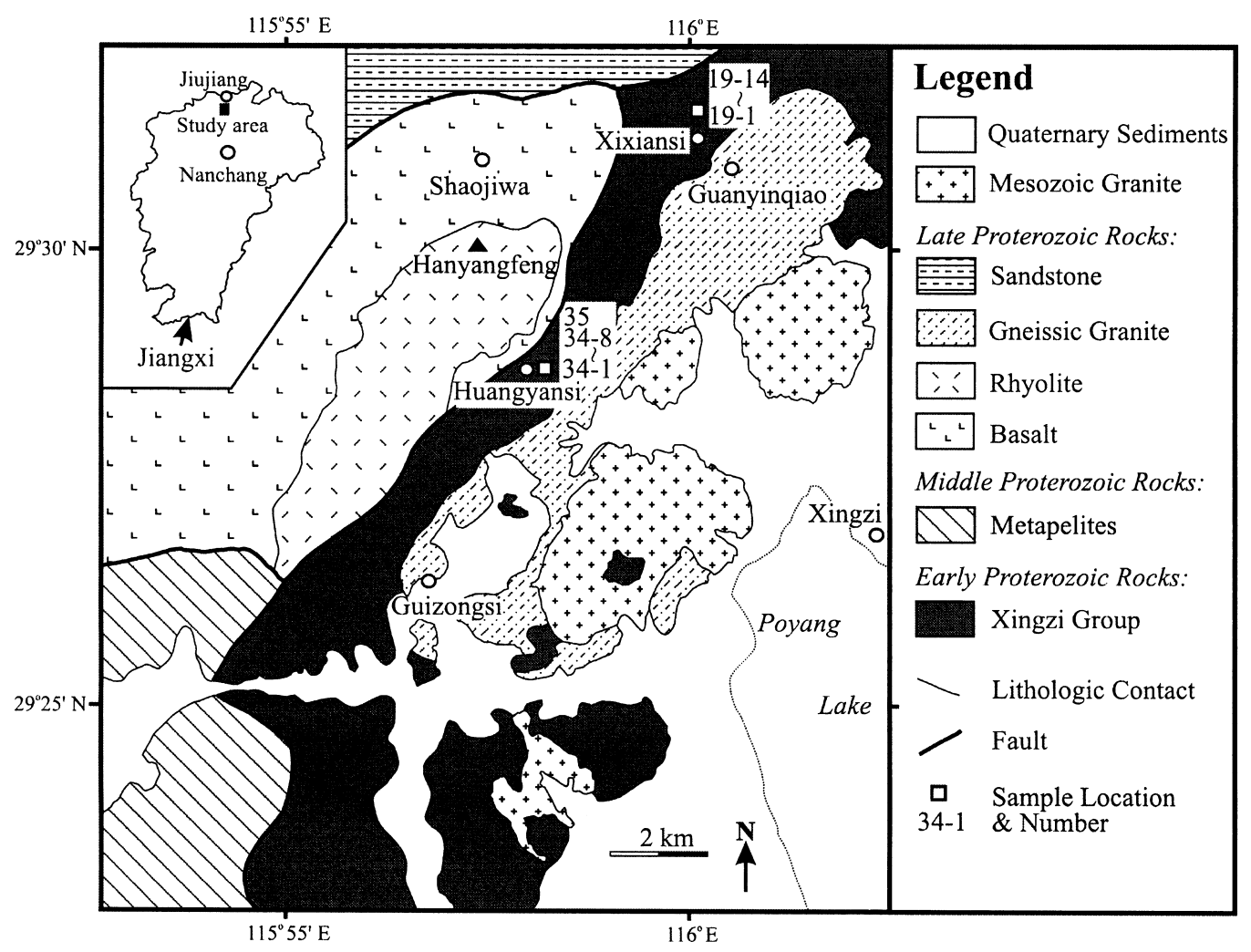

Fig. 1. Geological sketch map of the Lushan area showing the distribution of the Xingzi Group and sample locations. 


\section{Geological Setting}

The Xingzi Group crops out within the central part of the Late Proterozoic orogen along southeastern margin of Yangtze Block and is exposed as a NE trending belt in the Xixiansi-Guizongsi area, Xingzi County (Fig. 1). Its protolith is Paleoproterozoic, indicated by a single-zircon U$\mathrm{Pb}$ age of $1869 \pm 40 \mathrm{Ma}$ (Xie et al., 1997). Middle Proterozoic metapelites of the Shuangqiaoshan Group (Peng et al., 1995) unconformably overlie the Xingzi Group (Xie, 1997). The Late Proterozoic volcanic-sedimentary rocks include basalts (Shaojiwa Formation), rhyolites (Hanyangfeng Formation) and sandstones, which also uncomformably overlie the Xingzi group. The unconformity has been obscured as a result of later tectonic superimposition and is replaced by fault contact (Fig. 1). Field investigations indicate that the Late Proterozoic gneissic granites (Li et al., 1998) and Mesozoic granites (Xie et al., 1997) intruded the Xingzi Group.

The Xingzi Group primarily consists of metamorphosed psammites and pelites intercalated with minor metamorphosed basalts. All these rocks have amphibolite-facies metamorphic grade. Wang et al. (1992) estimated ranges of $420 \sim 580^{\circ} \mathrm{C}$ and 5.3 5.7 kbar for the peak temperatures and pressures, respectively. Based on our new electron microprobe data (unpublished), a similar estimation of the $P-T$ conditions ( $c a .5$ to $7 \mathrm{kbar}$, $550 \sim 680^{\circ} \mathrm{C}$ ) can be made. There has been no report on the age of metamorphism, but it most likely corresponds to the age of the Late Proterozoic orogeny in this area (Chen et al., 1991). Within the Xingzi Group metasedimentary rocks, many veins occur parallel to the regional schistosity. These veins are generally $10-100 \mathrm{~cm}$ wide and extend as much as several tens of meters. According to their modal mineral assemblage, the veins can be divided into two types, quartz and felsic (Table 1). The quartz veins are almost entirely made of quartz (>98 wt\%) and less than $2 \mathrm{wt} \%$ of muscovite and feldspar. They generally occur where metamorphosed psammites are immediate wallrocks. The felsic veins are mainly composed of quartz $(\sim 30 \mathrm{wt} \%)$ and feldspar $(\sim 50 \mathrm{wt} \%)$, as well as muscovite $(\sim 15-20 \mathrm{wt} \%)$, together with a

Table 1. Sample descriptions

\begin{tabular}{|c|c|c|c|c|}
\hline \multicolumn{2}{|c|}{ Sample No. } & \multirow[t]{2}{*}{ Vein type $^{1)}$} & \multirow[t]{2}{*}{ Wallrock type ${ }^{2)}$} & \multirow[t]{2}{*}{ Mineral assemblage of the wallrock ${ }^{3)}$} \\
\hline Vein & Immediate wallrock & & & \\
\hline \multicolumn{5}{|c|}{ Xixiansi: } \\
\hline $19-3$ & $19-2,19-4$ & Quartz & MP & Qtz-Pl-Bt \\
\hline $19-6$ & $19-7$ & Quartz & MP & Qtz-Pl-Bt \\
\hline $19-10$ & $19-9,19-11$ & Quartz & MP & Qtz-Pl-Bt \\
\hline $19-13$ & $19-12,19-14$ & Quartz & MP & Qtz-Pl-Bt \\
\hline \multicolumn{5}{|c|}{ Huangyansi: } \\
\hline $34-1$ & $34-5$ & Felsic & PS & Qtz-Bt-Mus-Grt-Pl \\
\hline $34-2$ & $34-6$ & Felsic & MP & Qtz-Pl-Bt-Grt \\
\hline $34-3$ & $34-7$ & Quartz & PS & Qtz-Bt-Mus-Grt-Pl \\
\hline \multirow[t]{2}{*}{$34-4$} & $34-8,35$ & Felsic & PS (34-8) & Qtz-Bt-Mus-Grt-Pl \\
\hline & & & $\mathrm{MP}(35)$ & Qtz-Grt-Bt-Pl \\
\hline
\end{tabular}

\footnotetext{
${ }^{1)}$ Divided by the major mineral compositions of the veins. Quartz veins are composed of quartz (>98 wt\%) and $<2 \mathrm{wt} \%$ of muscovite and feldspar. Felsic veins mainly quartz and feldspar and minor muscovite, in samples 34-2 and 34-4 additionally a small amount of garnet.

${ }^{2)} M P$ indicates metamorphosed psammite and PS indicates pelitic schist.

${ }^{3)}$ Major minerals in the order of decreasing amounts. In addition, magnetite, monazite and/or allanite occurring in most of the wallrock samples as the common accessory phases. Abbreviation for minerals: Qtz, quartz; Pl, plagioclase; Bt, biotite; Mus, muscovite; Grt, garnet.
} 
small amount of garnet ( $\leq 5 \mathrm{wt} \%)$ in some veins. These veins primarily occur within pelitic schists.

Several lines of evidence show that the veins were formed contemporaneously with the metamorphism: (1) the veins are parallel to the regional schistosity, in contrast with those of post-tectonic/ metamorphic origin, which cut the schistosity; (2) there is a close relationship in mineralogy between the veins and their wallrocks, suggesting that the vein compositions are directly buffered by their wallrocks; (3) no selvage (zones of wallrock alteration, termed after Ague, 1994) in the immediate wallrocks of the veins are observed in the field, and in detailed studies of polished samples. This last observation combined with the fact that some sheets of muscovite occur both in the veins and their immediate wallrocks, indicates that the veins are mineralogically equilibrated with the wallrocks, and hence the vein-forming materials are locally derived from the wallrocks. These field and petrographic features provide strong evidence that the veins formed during metamorphism, and hence can be regarded as synmetamorphic (Cesare, 1994; Henry et al., 1996). This conclusion is further confirmed by geochemical data presented in this paper.

\section{SAMPles ANd Analytical MethodS}

Twenty samples of the synmetamorphic veins and their wallrocks were collected from the Xingzi Group of Lushan at two locations, Xixiansi and Huangyanshi. The wallrocks at Xixianshi are metamorphosed psammites and Huangyansi mainly consist of pelitic schists (Fig. 1, Table 1). Petrographic thin sections (several for some rock samples) were made for all the wallrock and vein samples and carefully examined by optical microscopy and/or JCXA-733 electron microprobe. No REE- or other trace element-rich phases were found in any of the vein samples.

About 200 to $500 \mathrm{~g}$ samples were crushed, and then manually ground in an agate mortar. Mineral separates were prepared using the procedure of panning, magnetic and heavy liquid separation, and finally handpicking under a binocular micro- scope. For the garnet (especially those from the wallrocks) with quartz inclusions, several sieve fractions were made in order to get high purity. After the separation, the mineral separates were washed first with dilute $\mathrm{HCl}$ and then deionized water in an ultrasonic cleaner to eliminate any contaminant on the mineral surfaces.

Major elements were analyzed by standard wet chemical methods. $\mathrm{SiO}_{2}$ was determined using gravimetry after $\sim 0.5 \mathrm{~g}$ rock powders were dissolved in concentrated $\mathrm{NaOH}$. For other major elements, the rock powders $(\sim 0.1 \mathrm{~g})$ were dissolved using concentrated $\mathrm{HF}-\mathrm{HNO}_{3}$ mixture, $\mathrm{HF}$ and $\mathrm{HClO}_{4}$ orderly. After conversion to the chloride form with a little concentrated $\mathrm{HCl}$, three different methods were employed depending on their contents in the rocks, volumetric method for $\mathrm{Al}$, colorimetry for $\mathrm{Ti}$ and $\mathrm{P}$, and atomic absorption spectrometry (AAS) for $\mathrm{K}, \mathrm{Na}, \mathrm{Ca}, \mathrm{Mg}, \mathrm{Mn}$ and $\mathrm{Fe}$. Trace elements were determined on a Finnigan MAT ELEMENT high resolution ICP-MS in the Institute of Geochemistry, Chinese Academy of Sciences. The analytical methods have been described by Qi et al. (2000) and Qi and Grégoire (2000) and only a brief description is presented here. About $50 \mathrm{mg}$ of sample powders $(250 \mathrm{mg}$ for the quartz veins due to their quite low trace element abundances) were dissolved using a HF$\mathrm{HNO}_{3}$ mixture into closed Teflon bombs at $190^{\circ} \mathrm{C}$ for 12 hours. The solution containing rhodium element $(1 \mu \mathrm{g} / \mathrm{ml})$ was added as an internal standard. The residue after drying was re-dissolved by adding $40 \% \mathrm{HNO}_{3}$ and heating again. The final solution was made up to $50 \mathrm{ml}(25 \mathrm{ml}$ for the quartz veins) by the addition of distilled deionized water. For quality control, blanks and standards were run every five samples. The precision of the repeat analysis of the standard was always within $10 \%$, and the accuracy was generally better than $\pm 5 \%$ for the LREEs (light rare earth elements) and $\pm 10 \%$ for other trace elements. Oxygen isotope compositions of mineral separates were analyzed in the Isotope Laboratory, Institute of Mineral Ore Deposit Geology, Geological Academy of China. Oxygen was extracted using the conventional $\mathrm{BrF}_{5}$ method (Clayton and Mayeda, 1963) and quanti- 
tatively converter to $\mathrm{CO}_{2}$. Isotope ratios were measured on a MAT-251 mass spectrometer. All values of $\delta^{18} \mathrm{O}$ are reported as per mil (\%o) relative to SMOW and are accurate to $\pm 0.2 \%$.

\section{RESULTS}

The major element compositions of the metamorphic wallrocks and felsic veins are listed in Table 2. The most notable characteristic of the wallrocks is that the metamorphosed psammites have high abundances of $\mathrm{SiO}_{2}$ (generally >65 $\mathrm{wt} \%)$ and low abundances of $\mathrm{Al}_{2} \mathrm{O}_{3}(<18 \mathrm{wt} \%)$, whereas the pelitic schists have low $\mathrm{SiO}_{2}(56-63$ $\mathrm{wt} \%)$ and high $\mathrm{Al}_{2} \mathrm{O}_{3}(18-21 \mathrm{wt} \%)$. The major element compositions of the felsic veins are predominantly $\mathrm{SiO}_{2}, \mathrm{Al}_{2} \mathrm{O}_{3}$, and $\mathrm{Na}_{2} \mathrm{O}$, and a small amount of $\mathrm{K}_{2} \mathrm{O}$, consisted with quartz and feldspar as the major constituent minerals. The feldspar in these veins is albite.

Trace element data for the veins and their wallrocks are given in Table 3. The wallrocks at both locations have high LREE abundances (Fig. 2 , chondrite-normalized concentration of $\mathrm{La}$, $\left.\mathrm{La}_{\mathrm{N}}=60-186\right)$ and slightly fractionated REE patterns $\left(\mathrm{La}_{\mathrm{N}} / \mathrm{Yb}_{\mathrm{N}}=2.4-14\right)$. The negative Eu anomalies in the wallrocks are stronger at Xixiansi $(\mathrm{Eu} /$ $\left.\mathrm{Eu}^{*}=0.3-0.5\right)$ than at Huangyansi $\left(\mathrm{Eu} / \mathrm{Eu}^{*}=0.6-\right.$ $0.9)$. Figure 2 also shows that the individual chondrite-normalized REE patterns of the quartz veins at Xixiansi (Fig. 2a) are parallel to those of their immediate wallrocks, but at much lower absolute abundances. In contrast, the REE patterns of all veins at Huangyansi (both quartz and felsic) are quite different from those of their immediate wallrocks (Fig. 2b). They show HREE (heavy rare earth element) enrichments relative to the LREE $\left(\mathrm{La}_{\mathrm{N}} / \mathrm{Yb}_{\mathrm{N}}=0.69-2.87\right)$. It is also worth noting that the felsic veins have more pronounced negative Eu anomalies $\left(\mathrm{Eu} / \mathrm{Eu}^{*}=0.2-0.4\right)$ than those of their wallrocks, and that their REE patterns are irregular, with the characteristics of the REE tetrad effect (discussed in the following section).

All the wallrocks have quite uniform N-MORB normalized patterns for incompatible elements, characterized by remarkably high abundances of

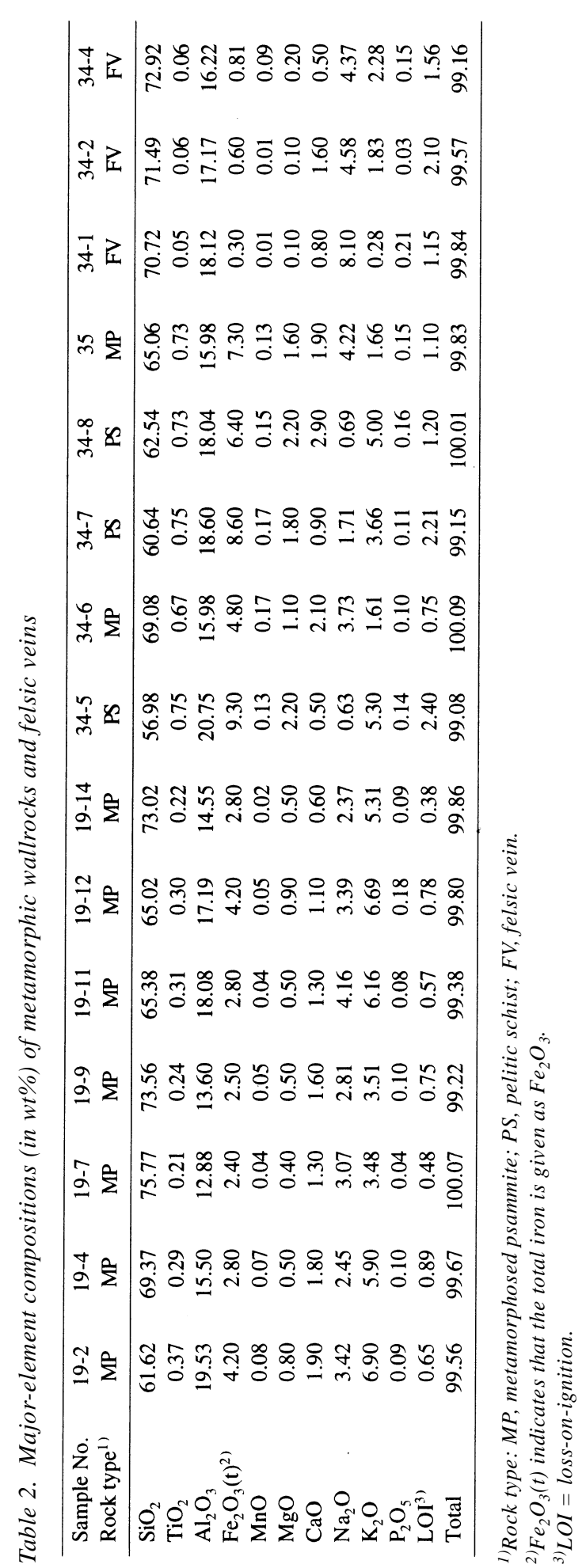


Table 3. Trace-element abundances (in ppm) of metamorphic veins and their wallrocks

\begin{tabular}{|c|c|c|c|c|c|c|c|c|c|c|c|c|}
\hline $\begin{array}{l}\text { Sample No. } \\
\text { Rock type }^{1)}\end{array}$ & $\begin{array}{l}19-2 \\
\text { MP }\end{array}$ & $\begin{array}{l}19-3 \\
Q V\end{array}$ & $\begin{array}{l}19-4 \\
\text { MP }\end{array}$ & $\begin{array}{l}19-6 \\
\text { QV }\end{array}$ & $\begin{array}{l}19-7 \\
\text { MP }\end{array}$ & $\begin{array}{l}19-9 \\
\text { MP }\end{array}$ & $\begin{array}{c}19-10 \\
\text { QV }\end{array}$ & $\begin{array}{c}\text { 19-11 } \\
\text { MP }\end{array}$ & $\begin{array}{c}19-12 \\
\text { MP }\end{array}$ & $\begin{array}{l}19-13 \\
\text { QV }\end{array}$ & $\begin{array}{c}19-14 \\
\text { MP }\end{array}$ & $\begin{array}{c}34-5 \\
\text { PS }\end{array}$ \\
\hline $\mathrm{La}$ & 43.5 & 0.595 & 26.2 & 0.60 & 14.0 & 17.1 & 0.592 & 14.6 & 22.8 & 0.508 & 20.2 & 25.7 \\
\hline $\mathrm{Ce}$ & 91.4 & 1.33 & 67.9 & 1.29 & 30.1 & 53.0 & 1.50 & 40.3 & 50.4 & 1.02 & 53.9 & 49.8 \\
\hline $\operatorname{Pr}$ & 11.3 & 0.172 & 7.79 & 0.190 & 3.90 & 5.12 & 0.142 & 4.10 & 5.78 & 0.150 & 5.63 & 6.49 \\
\hline $\mathrm{Nd}$ & 48.2 & 0.597 & 33.5 & 0.636 & 14.4 & 19.8 & 0.576 & 15.4 & 22.9 & 0.583 & 21.8 & 25.5 \\
\hline $\mathrm{Sm}$ & 10.7 & 0.184 & 7.51 & 0.155 & 3.14 & 4.17 & 0.116 & 3.87 & 5.10 & 0.160 & 4.70 & 5.81 \\
\hline $\mathrm{Eu}$ & 1.15 & 0.027 & 0.93 & 0.022 & 0.412 & 0.478 & 0.0132 & 0.568 & 0.59 & 0.020 & 0.55 & 1.03 \\
\hline Gd & 9.62 & 0.179 & 7.40 & 0.149 & 3.00 & 3.91 & 0.122 & 3.13 & 3.92 & 0.169 & 3.55 & 4.55 \\
\hline $\mathrm{Tb}$ & 1.66 & 0.033 & 1.38 & 0.025 & 0.58 & 0.62 & 0.0196 & 0.54 & 0.56 & 0.029 & 0.49 & 0.70 \\
\hline Dy & 10.9 & 0.229 & 9.26 & 0.133 & 4.29 & 3.84 & 0.118 & 3.79 & 3.54 & 0.166 & 2.72 & 4.01 \\
\hline Ho & 2.05 & 0.054 & 1.81 & 0.026 & 0.89 & 0.80 & 0.0191 & 0.77 & 0.63 & 0.031 & 0.39 & 0.79 \\
\hline Er & 6.27 & 0.175 & 5.78 & 0.063 & 3.10 & 2.52 & 0.0507 & 2.34 & 1.96 & 0.081 & 1.07 & 2.20 \\
\hline $\mathrm{Tm}$ & 0.82 & 0.024 & 0.70 & 0.008 & 0.39 & 0.35 & 0.0066 & 0.29 & 0.23 & 0.011 & 0.14 & 0.28 \\
\hline $\mathrm{Yb}$ & 5.75 & 0.173 & 5.36 & 0.059 & 2.98 & 2.59 & 0.0441 & 2.33 & 1.93 & 0.066 & 1.01 & 2.05 \\
\hline $\mathrm{Lu}$ & 0.82 & 0.026 & 0.75 & 0.009 & 0.42 & 0.39 & 0.0057 & 0.34 & 0.27 & 0.012 & 0.16 & 0.34 \\
\hline $\mathrm{Y}$ & 54.5 & 1.53 & 46.1 & 0.662 & 23.2 & 20.9 & 0.506 & 18.5 & 15.0 & 0.849 & 9.85 & 18.3 \\
\hline $\mathrm{Rb}$ & 171 & 2.61 & 154 & 2.28 & 76.7 & 87.0 & 0.127 & 133 & 140 & 0.951 & 107 & 828 \\
\hline $\mathrm{Sr}$ & 67.2 & 1.99 & 51.3 & 1.68 & 30.8 & 43.2 & 0.448 & 55.0 & 34.0 & 1.17 & 20.2 & 23.8 \\
\hline $\mathrm{Ba}$ & 873 & 13.8 & 870 & 11.8 & 378 & 504 & 2.82 & 778 & 567 & 2.63 & 552 & 422 \\
\hline $\mathrm{Zr}$ & 180 & 0.662 & 115 & 0.807 & 113 & 89.3 & 0.839 & 138 & 124 & 0.243 & 89.2 & 86.0 \\
\hline $\mathrm{Hf}$ & 6.49 & 0.066 & 4.12 & 0.048 & 4.13 & 3.24 & 0.355 & 5.28 & 4.60 & 0.007 & 4.11 & 4.69 \\
\hline $\mathrm{Nb}$ & 14.6 & 0.449 & 11.8 & 0.471 & 9.09 & 9.60 & 0.015 & 12.2 & 15.4 & 0.202 & 10.1 & 11.6 \\
\hline $\mathrm{Ta}$ & 1.71 & 0.131 & 1.03 & 0.125 & 0.70 & 0.73 & 0.0019 & 1.01 & 2.33 & 0.021 & 0.77 & 0.80 \\
\hline $\mathrm{Pb}$ & 23.2 & 1.34 & 18.4 & 1.55 & 8.62 & 8.26 & 5.60 & 8.36 & 37.0 & 2.91 & 14.7 & 5.89 \\
\hline Th & 17.4 & 0.168 & 12.7 & 0.234 & 8.25 & 9.31 & 0.106 & 12.6 & 11.2 & 0.048 & 8.32 & 5.93 \\
\hline $\mathrm{U}$ & 4.01 & 0.553 & 2.61 & 0.085 & 1.82 & 2.14 & 0.035 & 2.39 & 2.36 & 0.071 & 1.34 & 3.59 \\
\hline $\left.\mathrm{Eu} / \mathrm{Eu}^{* 2}\right)$ & 0.34 & 0.45 & 0.38 & 0.44 & 0.41 & 0.36 & 0.34 & 0.50 & 0.40 & 0.37 & 0.41 & 0.61 \\
\hline $\mathrm{La}_{\mathrm{N}} / \mathrm{Yb}_{\mathrm{N}}{ }^{2)}$ & 5.24 & 2.38 & 3.38 & 7.04 & 3.25 & 4.57 & 9.29 & 4.34 & 8.18 & 5.33 & 13.85 & 8.68 \\
\hline
\end{tabular}

large ion lithophile elements (LILEs), strong negative anomalies of $\mathrm{Nb}, \mathrm{Sr}$ and $\mathrm{Eu}$, and strong positive anomaly of $\mathrm{Pb}$, except for the samples 34-5 and 34-8, which have much higher $\mathrm{Rb}$ abundances than other samples (Table 3, Fig. 3a). It is worth noting that the wallrocks have generally similar patterns to the continental crust estimated by Rudnick (1995), however, the pronounced $\mathrm{Sr}$ and Eu troughs seen in the patterns of the wallrocks suggest that the crustal materials in southeast China were most likely formed through strong fractionation of plagioclase. In general, The quartz veins at Xixiansi have similar trace element patterns as their wallrocks, but tend to have much lower abundances and notably variant $\mathrm{U}, \mathrm{Nb}, \mathrm{Ta}$, $\mathrm{Zr}$, and Hf (Fig. 3b). The felsic veins at Huangyansi also have high abundances of most LILEs. However, the marked troughs at $\mathrm{Ba}, \mathrm{La}-$ $\mathrm{Pr}$, and $\mathrm{Eu}$ and peaks at $\mathrm{U}$ and $\mathrm{Ta}$ in the patterns (Fig. 3c) make them much different from their wallrocks. Compared to other veins, the quartz vein at Huangyansi (sample 34-3) also has a notable U enrichment (Fig. 3c) but there is no negative $\mathrm{Sr}$ anomaly or $\mathrm{Nb}-\mathrm{Ta}$ trough as seen in the quartz veins at Xixiansi.

The oxygen isotopic compositions of the mineral separates including quartz, garnet, and plagioclase from both the veins and their wallrocks are presented in Table 4 . The quartz separates from both the veins and their wallrocks have similar $\delta^{18} \mathrm{O}$ ranges. The ranges are from 11.0 to $13.5 \%$ o for the veins and from 11.0 to $12.9 \%$ for their wallrocks. The garnet in sample 34-4 (a felsic vein) has $\delta^{18} \mathrm{O}$ value of $8.3 \%$; this value is nearly identical to that of the garnet from its immediate wallrock (sample 35). The plagioclases from three felsic veins have rather uniform $\delta^{18} \mathrm{O}$ values $(10.2$ to $10.3 \%$ o). The order of ${ }^{18} \mathrm{O}$ enrichment in the felsic veins is quartz > plagioclase > garnet, in agreement with that in common rock-forming minerals (Garlick and Epstein, 1967). 
Table 3. (continued)

\begin{tabular}{|c|c|c|c|c|c|c|c|c|c|c|c|}
\hline $\begin{array}{l}\text { Sample No. } \\
\text { Rock type }^{1)}\end{array}$ & $\begin{array}{l}34-1 \\
F V\end{array}$ & $\begin{array}{c}34-6 \\
\text { MP }\end{array}$ & $\begin{array}{l}34-2 \\
F V\end{array}$ & $\begin{array}{c}34-7 \\
\text { PS }\end{array}$ & $\begin{array}{c}34-7 \\
\text { (Garnet) }\end{array}$ & $\begin{array}{l}34-3 \\
Q V\end{array}$ & $\begin{array}{c}34-8 \\
\text { PS }\end{array}$ & $\begin{array}{c}34-4 \\
F V\end{array}$ & $\begin{array}{c}34-4 \\
\text { (Garnet) }\end{array}$ & $\begin{array}{c}35 \\
\text { MP }\end{array}$ & $\begin{array}{c}35 \\
\text { (Garnet) }\end{array}$ \\
\hline $\mathrm{La}$ & 2.19 & 17.9 & 7.39 & 28.5 & 21.5 & 0.198 & 29.9 & 0.790 & 1.26 & 38.2 & 19.4 \\
\hline $\mathrm{Ce}$ & 4.67 & 35.2 & 16.6 & 58.2 & 45.7 & 0.593 & 61.5 & 1.61 & 3.03 & 78.9 & 41.4 \\
\hline $\mathrm{Pr}$ & 0.60 & 4.36 & 2.03 & 7.32 & 5.56 & 0.060 & 7.68 & 0.240 & 0.386 & 10.2 & 4.95 \\
\hline $\mathrm{Nd}$ & 2.37 & 17.1 & 7.94 & 29.0 & 20.8 & 0.151 & 30.0 & 0.794 & 1.09 & 38.8 & 20.0 \\
\hline $\mathrm{Sm}$ & 0.91 & 3.66 & 2.50 & 6.22 & 5.60 & 0.043 & 6.10 & 0.482 & 1.19 & 8.98 & 5.85 \\
\hline $\mathrm{Eu}$ & 0.12 & 1.03 & 0.16 & 1.47 & 1.42 & 0.018 & 1.16 & 0.058 & 0.113 & 1.66 & 1.28 \\
\hline $\mathrm{Gd}$ & 0.96 & 3.01 & 2.15 & 4.93 & 14.3 & 0.047 & 5.07 & 0.409 & 4.84 & 8.00 & 21.4 \\
\hline $\mathrm{Tb}$ & 0.26 & 0.47 & 0.44 & 0.79 & 5.05 & 0.012 & 0.71 & 0.100 & 2.47 & 1.31 & 8.79 \\
\hline Dy & 1.46 & 2.92 & 3.14 & 5.20 & 52.0 & 0.092 & 4.27 & 0.560 & 20.3 & 8.28 & 90.6 \\
\hline Ho & 0.27 & 0.52 & 0.55 & 0.99 & 14.3 & 0.032 & 0.80 & 0.067 & 3.95 & 1.53 & 24.1 \\
\hline $\mathrm{Er}$ & 0.94 & 1.65 & 1.76 & 3.23 & 51.6 & 0.128 & 2.37 & 0.205 & 14.6 & 4.68 & 80.9 \\
\hline $\mathrm{Tm}$ & 0.14 & 0.22 & 0.25 & 0.47 & 8.41 & 0.021 & 0.29 & 0.031 & 2.91 & 0.56 & 12.3 \\
\hline $\mathrm{Yb}$ & 1.12 & 1.96 & 1.78 & 3.49 & 61.6 & 0.199 & 2.14 & 0.249 & 24.9 & 4.16 & 82.4 \\
\hline $\mathrm{Lu}$ & 0.11 & 0.31 & 0.24 & 0.53 & 11.1 & 0.036 & 0.33 & 0.032 & 4.41 & 0.61 & 14.0 \\
\hline $\mathrm{Y}$ & 8.83 & 14.0 & 15.2 & 24.5 & 367 & 0.940 & 19.2 & 2.80 & 155 & 38.8 & 398 \\
\hline $\mathrm{Rb}$ & 27.3 & 47.3 & 43.4 & 124 & 7.08 & 0.429 & 562 & 119 & 9.85 & 69.7 & 6.72 \\
\hline $\mathrm{Sr}$ & 15.3 & 65.4 & 18.4 & 79.0 & 1.66 & 2.97 & 17.2 & 5.38 & 1.14 & 101 & 1.30 \\
\hline $\mathrm{Ba}$ & 22.7 & 218 & 60.5 & 620 & 8.44 & 4.78 & 365 & 22.1 & 5.03 & 515 & 7.82 \\
\hline $\mathrm{Zr}$ & 39.2 & 102 & 19.1 & 75.2 & 140 & 0.023 & 57.3 & 17.2 & 88.0 & 64.1 & 78.5 \\
\hline $\mathrm{Hf}$ & 2.18 & 3.06 & 1.02 & 2.36 & 4.19 & 0.006 & 1.72 & 1.66 & 8.24 & 2.18 & 2.36 \\
\hline $\mathrm{Nb}$ & 21.0 & 8.69 & 10.5 & 12.7 & 4.14 & 0.192 & 12.2 & 70.2 & 36.1 & 12.3 & 3.04 \\
\hline $\mathrm{Ta}$ & 9.21 & 0.52 & 2.53 & 0.86 & 0.598 & 0.010 & 0.83 & 9.88 & 13.1 & 0.84 & 0.384 \\
\hline $\mathrm{Pb}$ & 4.59 & 13.3 & 17.6 & 10.9 & 2.56 & 1.39 & 4.98 & 3.86 & 1.57 & 17.4 & 2.03 \\
\hline Th & 7.07 & 4.28 & 4.62 & 7.56 & 7.87 & 0.036 & 8.81 & 0.250 & 3.98 & 12.6 & 7.07 \\
\hline $\mathrm{U}$ & 14.0 & 2.80 & 10.0 & 1.61 & 2.85 & 0.065 & 3.79 & 4.20 & 46.4 & 2.48 & 2.18 \\
\hline $\left.\mathrm{Eu} / \mathrm{Eu}^{* 2}\right)$ & 0.39 & 0.94 & 0.21 & 0.81 & 0.48 & 1.22 & 0.63 & 0.400 & 0.14 & 0.59 & 0.35 \\
\hline $\mathrm{La}_{\mathrm{N}} / \mathrm{Yb}_{\mathrm{N}}{ }^{2)}$ & 1.35 & 6.32 & 2.87 & 5.65 & 0.24 & 0.69 & 9.67 & 2.20 & 0.04 & 6.36 & 0.16 \\
\hline
\end{tabular}

${ }^{1)}$ Rock type: MP, metamorphosed psammite; PS, pelitic schist; QV, quartz vein; FV, felsic vein. Labeled by brackets are the mineral garnets in the wallrocks and one felsic vein at Huangyansi.

${ }^{2)} \mathrm{Eu} / \mathrm{Eu} *=E u_{N} /\left[\left(S m_{N}\right) \times\left(G d_{N}\right)\right]^{0.5}$, where $N$ stands for normalization by C1-chondrite of which REE data is after Anders and Grevesse (1989).

\section{DISCUSSION}

\section{Origin of vein-forming fluids}

A number of studies have shown that quartz veins in metamorphic terrains must be precipitated from silica-rich fluids produced by dehydration during metamorphism (e.g., Yardley, 1983; Yardley and Bottrell, 1992; Ague, 1991; Henry et al., 1996; Wilkinson et al., 1996). In addition, some feldspar-bearing veins (Vidale, 1974), quartz- $\mathrm{Al}_{2} \mathrm{SiO}_{5}$ veins (Putlitz et al., 2002), and high-pressure veins (Becker et al., 1999) in metamorphic rocks also been formed from fluids with the same origin as that of quartz veins. Like the discussion made by Becker et al. (1999), it might be argued that the felsic veins at Huangyansi are frozen partial melts of the pelites, because large amounts of feldspar occur in the veins and the temperatures at which the rocks were metamorphosed were relatively close to the water-saturated solidus of pelitic sediments $\left(\sim 640-670^{\circ} \mathrm{C}\right.$ at $5-10 \mathrm{kbar}$, Nichols et al., 1994). However, the differential fractionation of highly incompatible trace elements in the felsic veins and their wallrocks does not support this consideration. For example, in the case of melting it might be expected that Ba would show enrichment in the veins comparable to $\mathrm{Rb}$, Th, and U. This is not observed (Fig. 3c). In addition, the fractionation of some geochemical pairs (Nb-Ta, Zr-Hf, Pb-Nd) and the REE tetrad effect (discussed in detail below) also argue against this consideration. Furthermore, if the felsic veins were crystallized partial melts of the crustal materials in the study area, they should most likely have 
(a) Xixiansi
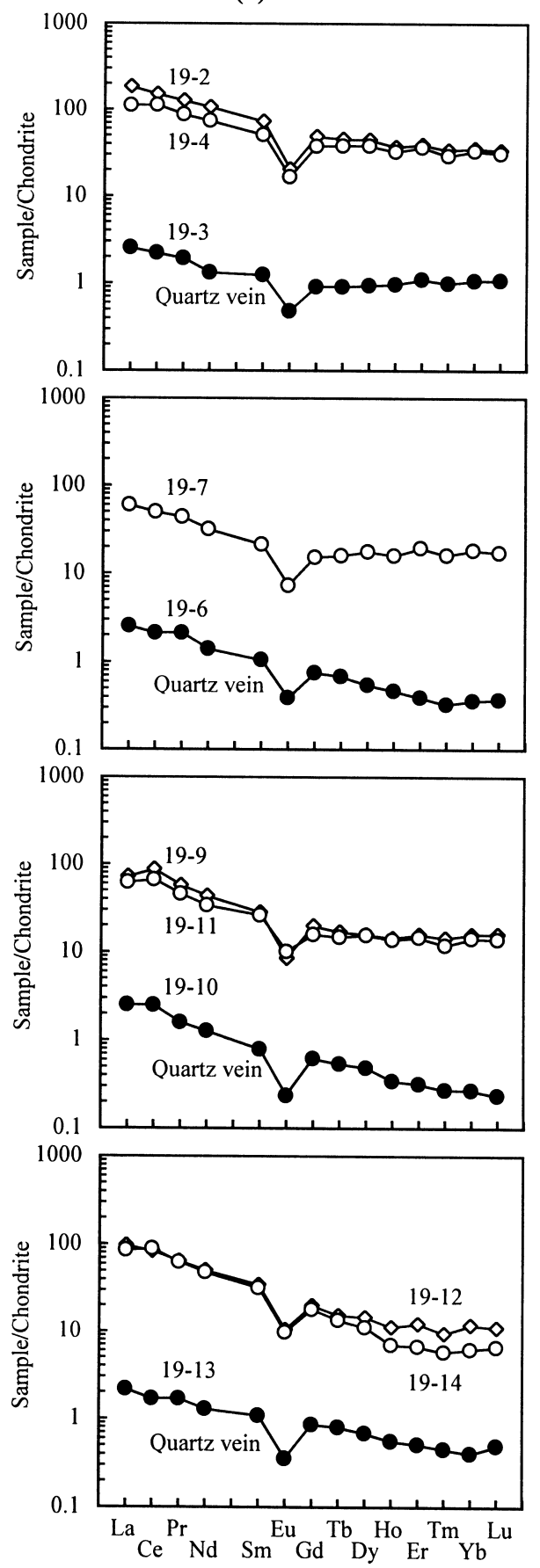

(b) Huangyansi
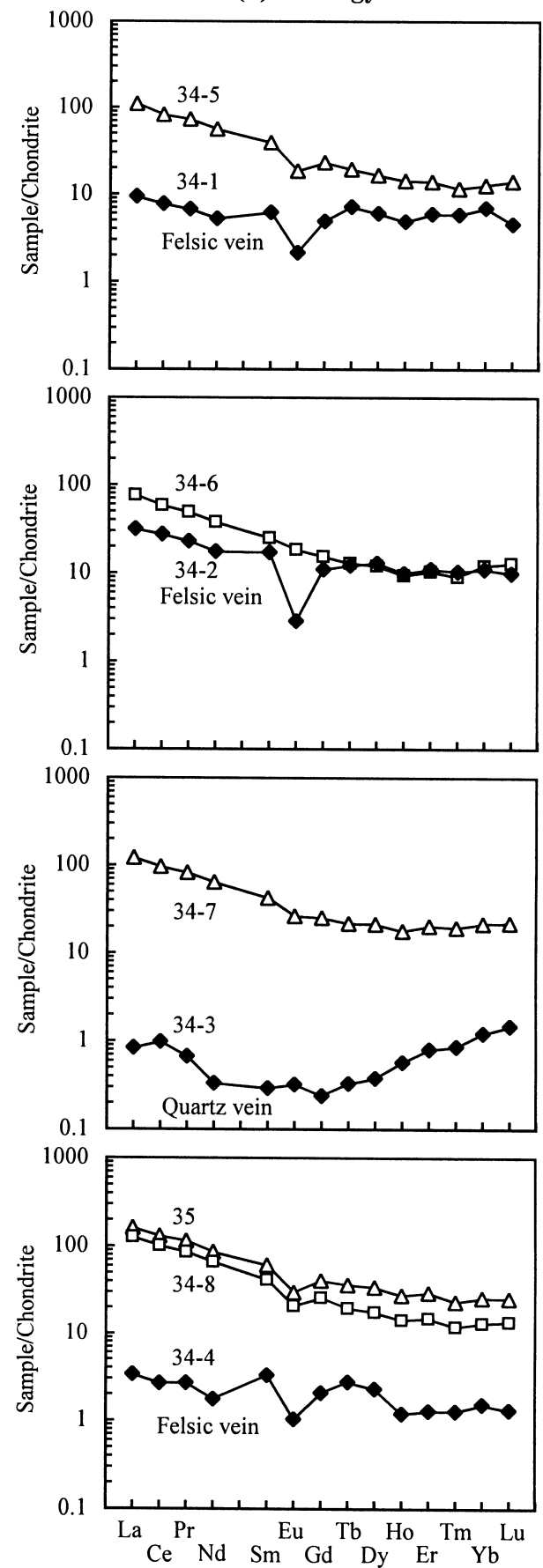

Fig. 2. Chondrite-normalized REE patterns of the synmetamorphic veins (filled symbols) and their immediate wallrocks (open symbols) at Xixiansi (a) and Huangyansi (b) in Lushan area. Sample numbers next to individual patterns are the same as in Table 3. Normalizing values from Anders and Grevesse (1989). 

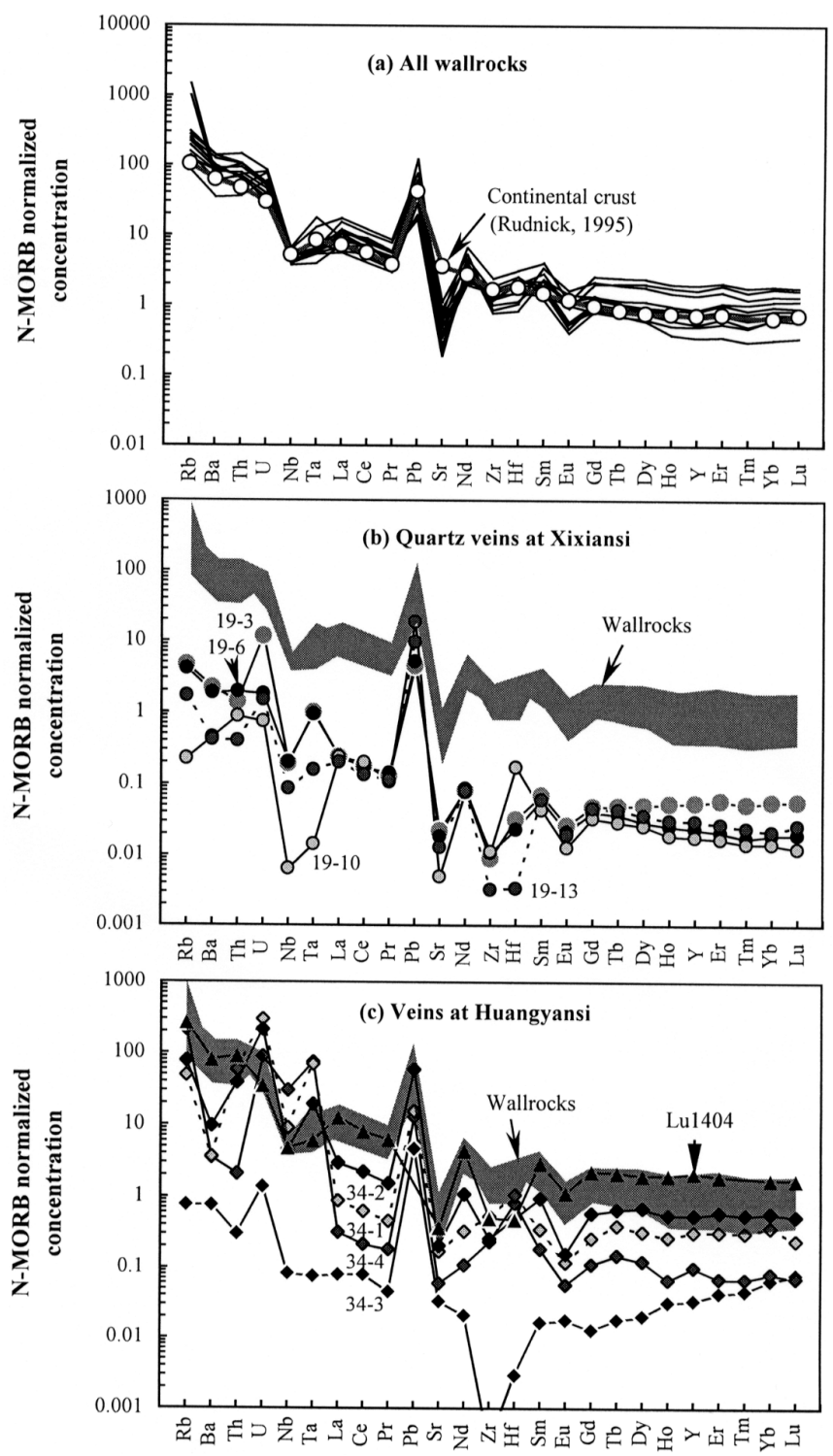

Fig. 3. N-MORB-normalized diagrams for incompatible trace elements in (a) all wallrocks, (b) quartz veins at Xixiansi, and (c) veins at Huangyansi of the Xingzi Group. Also shown the data of continental crust from Rudnick (1995) in (a) and Lu1404 (a sample of magmatic granite in Lushan) from Li et al. (1998) for comparison. Normalizing values from Sun and McDonough (1989).

had the similar trace element characteristics as the granite in this area, which has almost the same pattern as those of the wallrocks (Fig. 3c, sample Lu1404 after Li et al., 1998). Studies of fluid inclusions further indicate that the felsic veins are significantly different from the igneous granite in the region (Tang et al., 2000). Therefore, we con- clude that the felsic veins, like the similar synmetamorphic veins in other terrains (Putlitz et al., 2002; Becker et al., 1999), were deposited by fluids.

Previous studies of quartz veins occurring in metamorphic terrains suggest that the vein-forming fluids are either derived from the wallrocks 
Table 4. Oxygen isotopic compositions of mineral separates in synmetamorphic veins and their wallrocks

\begin{tabular}{llcc}
\hline Sample No. & Mineral & $\begin{array}{c}\delta^{18} \mathrm{O} \\
(\% \text { vs. SMOW })\end{array}$ & $\begin{array}{c}\delta^{18} \mathrm{O}_{\text {fluid }}{ }^{*} \\
(\% \text { vs. SMOW })\end{array}$ \\
\hline \multicolumn{2}{l}{ Synmetamorphic veins: } & & \\
$19-3$ & Quartz & 13.1 & 11.4 \\
$19-6$ & Quartz & 12.3 & 10.6 \\
$19-10$ & Quartz & 13.5 & 11.8 \\
$19-13$ & Quartz & 13.2 & 11.5 \\
$34-1$ & Quartz & 12.0 & 10.3 \\
& Plagioclase & 10.3 & 9.9 \\
$34-2$ & Quartz & 11.3 & 9.6 \\
& Plagioclase & 10.2 & 9.8 \\
$34-3$ & Quartz & 13.2 & 11.5 \\
$34-4$ & Quartz & 11.0 & 9.3 \\
& Plagioclase & 10.3 & 9.9 \\
& Garnet & 8.3 & 10.4 \\
Wallrocks: & & & \\
$19-2$ & Quartz & 12.9 & 11.2 \\
$19-14$ & Quartz & 12.5 & 10.8 \\
$34-7$ & Garnet & 9.6 & 11.7 \\
35 & Quartz & 11.0 & 9.3 \\
& Garnet & 8.0 & 10.1 \\
\hline
\end{tabular}

$* \delta^{18} O_{\text {fluid }}$ is the oxygen isotopic compositions of the fluids in equilibrium with selected minerals (quartz, plagioclase, and garnet) in the synmetamorphic veins and their wallrocks, estimated by the fractionation data of Javoy (1977) and $T=$ $600^{\circ} \mathrm{C}$.

(Yardley, 1975; Yardley and Bottrell, 1992; Putlitz et al., 2002) or partly ( 30\%) from an external source (Ague, 1994; van Haren et al., 1996). In the case of a partly external source, fluids migrate in a channelized way (i.e., the veins are the major conduits of migrating fluids), and are mineralogically and isotopically in disequilibrium with their wallrocks (Ague, 1994; van Haren et al., 1996). However, because no selvages were found in the wallrocks studied, and the oxygen isotopic data between the veins and their immediate wallrocks show a strong correspondance, we consider that the vein-forming fluids in the Xingzi Group were directly derived from the wallrocks. Figure 4 shows that the same mineral separates from coexisting vein-wallrock pairs have nearly the same $\delta^{18} \mathrm{O}$ values within the error, suggesting that the veins were locally derived and in equilibrium with their immediate wallrocks. In other words, the oxygen isotopic composition of the

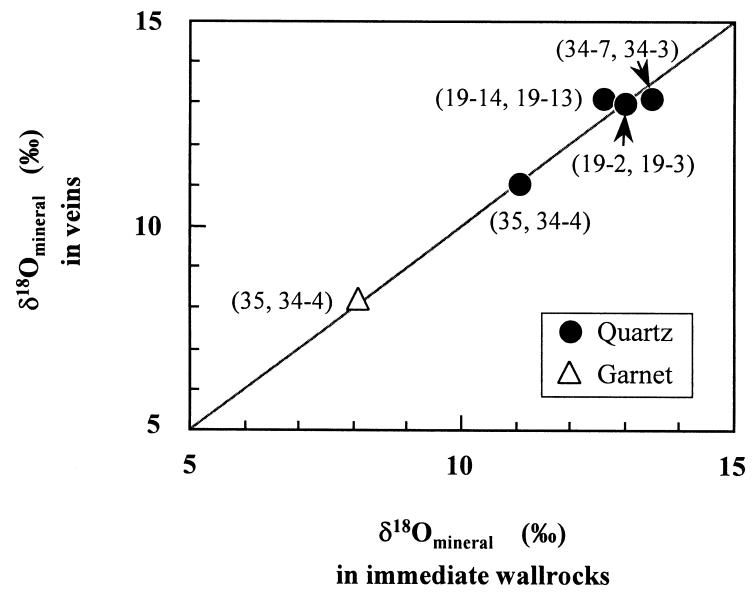

Fig. 4. $\delta^{18} O$ values of mineral separates from the veinimmediate wallrock pairs (labeled in brackets are the same sample numbers as in Table 4) showing their general equilibrium in oxygen isotope. The $\delta^{18} O$ value for quartz in sample 34-7 is calculated from that of garnet on the basis of the fractionation data of Javoy (1977) and $\mathrm{T}=600^{\circ} \mathrm{C}$.

vein-forming fluids was buffered by the local wallrocks.

On the basis of the fractionation data of Javoy (1977), and $\mathrm{T}=600^{\circ} \mathrm{C}$, at which the wallrocks were metamorphosed, we can estimate the oxygen isotopic compositions of the fluids equilibrated with individual minerals in the veins and their wallrocks. The estimated results range from 10.6 to $11.8 \%$ o (mean $11.2 \%, n=6$ ) for Xixiansi and from 9.3 to $11.7 \%$ (mean $10.2 \%$ o, $n=11$ ) for Huangyansi (Table 4, Fig. 5). Because the distance between Xixiansi and Huangyansi is not large ( 6 km, Fig. 1), the different $\delta^{18} \mathrm{O}_{\text {fluid }}$ values at these two locations do not support a pervasive fluid flow on a relatively large scale during regional metamorphism of the Xingzi Group.

Fractionation of trace elements during metamorphic dehydration

The veins at Huangyansi, particularly the felsic veins and their constituent minerals (e.g., garnet), have complicated and irregular REE patterns with the characteristics of the so-called lanthanide (or REE) tetrad effect (Figs. 2b and 6), a phenom- 
enon reported by Peppard et al. (1969) after they carried out studies of liquid-liquid extraction. As shown in Fig. 6a, the veins at Huangyansi have similar REE patterns and degrees of the tetrad effect as the rocks of a granite body (L14, from Irber, 1999) and a leucogranitic gneiss (3188WR, from Lee et al., 1994). In Fig. 6b, the garnet in sample 34-4 has the same pattern as 3188GT which ex-

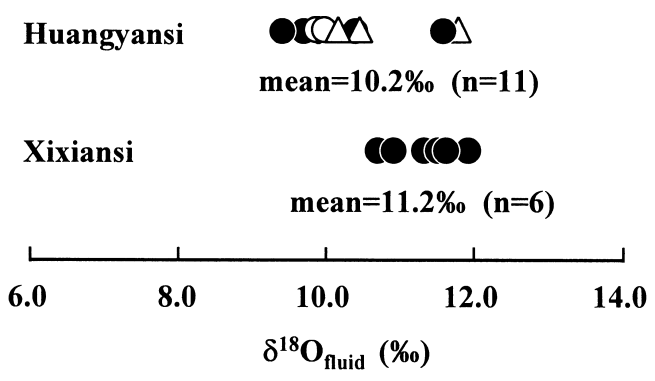

Mineral: Quartz $\bigcirc$ Plagioclase $\bigcirc$ Garnet $\triangle$

Fig. 5. Oxygen isotopic compositions for the metamorphic fluids in equilibrium with some minerals from Xixiansi and Huangyansi of the Xingzi Group, estimated by the fractionation data of Javoy (1977) and $T=$ $600^{\circ} \mathrm{C}$. hibits the REE tetrad effect (Lee et al., 1994). Although high LREE compositions in the garnets are likely due to the occurrence of possible submicroscopic inclusions of phosphates, the HREE parts in the patterns of the garnets from samples 34-4 and 3188 are also much different from those of the wallrocks. We hence consider that the irregular patterns especially the HREE parts of the garnet in samples 34-4 and 3188 exhibit the tetrad phenomenon. Because the REEs are a group of elements with identical charge $\left(3^{+}\right.$under most geologically related oxidation conditions) and a relative narrow range of ionic radius (from 1.03 $\AA$ for $\mathrm{La}^{3+}$ to $0.86 \AA$ for $\mathrm{Lu}^{3+}$ in VI coordination; Shannon, 1976), they tend to have almost the same behaviour and exhibit smooth patterns during many geological processes, especially in the silicate-melt systems. The REE tetrad effect is, therefore, a rare type of fractionation behaviour, which has attracted the attention of geochemists.

Since Masuda and Ikeuchi (1979) first pointed out the occurrence of the lanthanide tetrad effect in the marine environment, it has been recognized that this effect probably exists in many other natural samples, such as leucogranites (Masuda and
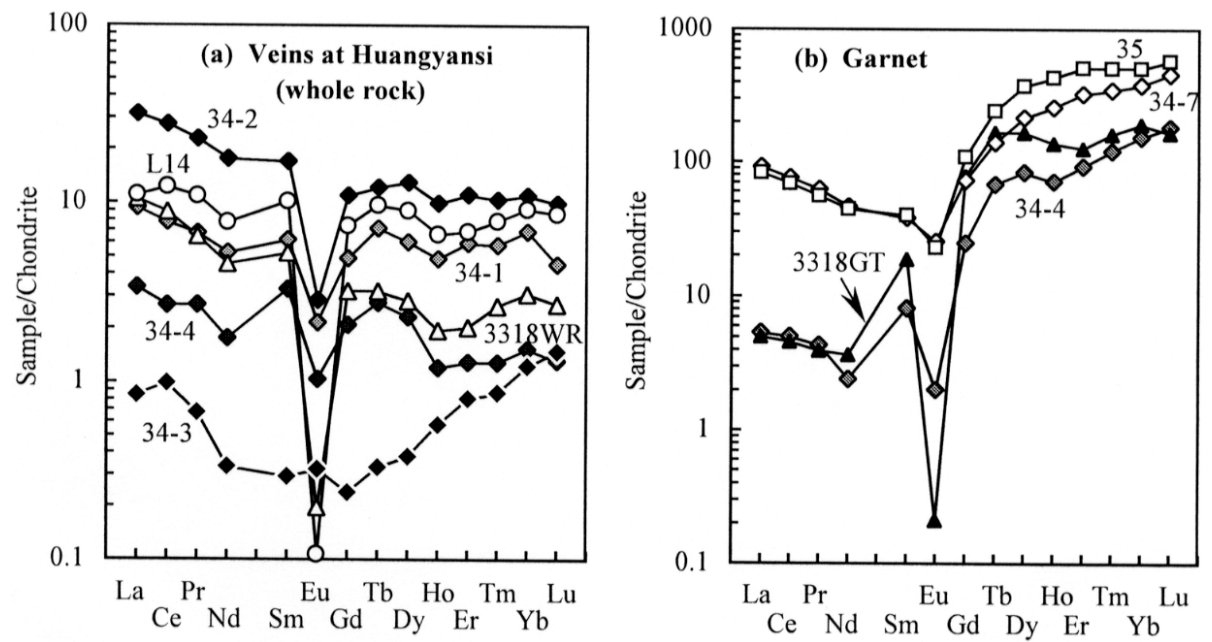

Fig. 6. Chondrite-normalized REE patterns with apparent tetrad effects for (a) wholerock of veins at Huangyansi, L14 and 3318 are granite and leucogranitic gneiss after Irber (1999) and Lee et al. (1994), respectively, and (b) garnets in sample 34-4 of the Xingzi Group and in the leucogranitic gneiss (3188GT) after Lee et al. (1994), also shown are the garnets in the wallrocks (samples 34-7 and 35) of the Xingzi Group for comparison. Normalizing values from Anders and Grevesse (1989). 
Akagi, 1989; Bau, 1996; Irber, 1999), limestones (Kawabe et al., 1991), uraninites (Hidaka et al., 1992), Quaternary sediments (Liu et al., 1993), kimuraite (Akagi et al., 1993), leucogranitic gneiss (Lee et al., 1994), and cherts (Minami et al., 1998). Although some geochemists have argued against its existence in natural environments (e.g., McLennan, 1994) and attributed the anomalous REE patterns in some leucogranites to fractional crystallization of individual mineral phases such as apatite (Jolliff et al., 1989), monazite (Zhao and Copper, 1992; Pan, 1997), or garnet and possible Y-rich accessory phases (Pan, 1997), the existence of the tetrad effect in natural environments is supported by an increasing body of data. Irregular REE patterns in some highly evolved felsic igneous rocks cannot be adequately explained by any fractional crystallization of accessory minerals (Bau, 1997). Lee et al. (1994) have particularly demonstrated that the rock-forming minerals in the leucogranitic gneiss, like their host rocks, also show the REE tetrad effect. Note that in Fig. 6b the garnet in sample 34-4 (a felsic vein) has a similar REE tetrad effect pattern to that from Lee $e t$ al. (1994), and much different from those in the wallrocks of the Xingzi Group (samples 34-7, and 35), which have smooth REE patterns. This further attests to the impossibility for the irregular REE patterns in rocks resulting from the fractional crystallization of some minerals. Hence the unusual REE patterns of some minerals as well as their host rocks cannot be explained by the ionic radius effect, and can only be understood by referring to the electronic configuration of these elements, which plays an important role in the complexes they form in fluid-rich systems. Based on the data of Henry et al. (1996), Kamber and Collerson (2000) recently showed that the REE fractionation (tetrad effect) also exists in synmetamorphic veins formed during metamorphic dehydration in the western Alps. Thus, it appears that the cases with the tetrad effect are closely related to fluids, and usually accompanied by the fractionation of trace elements with identical charge and similar radius (Liu et al., 1993; Bau, 1996; Irber, 1999; Minami et al., 1998).
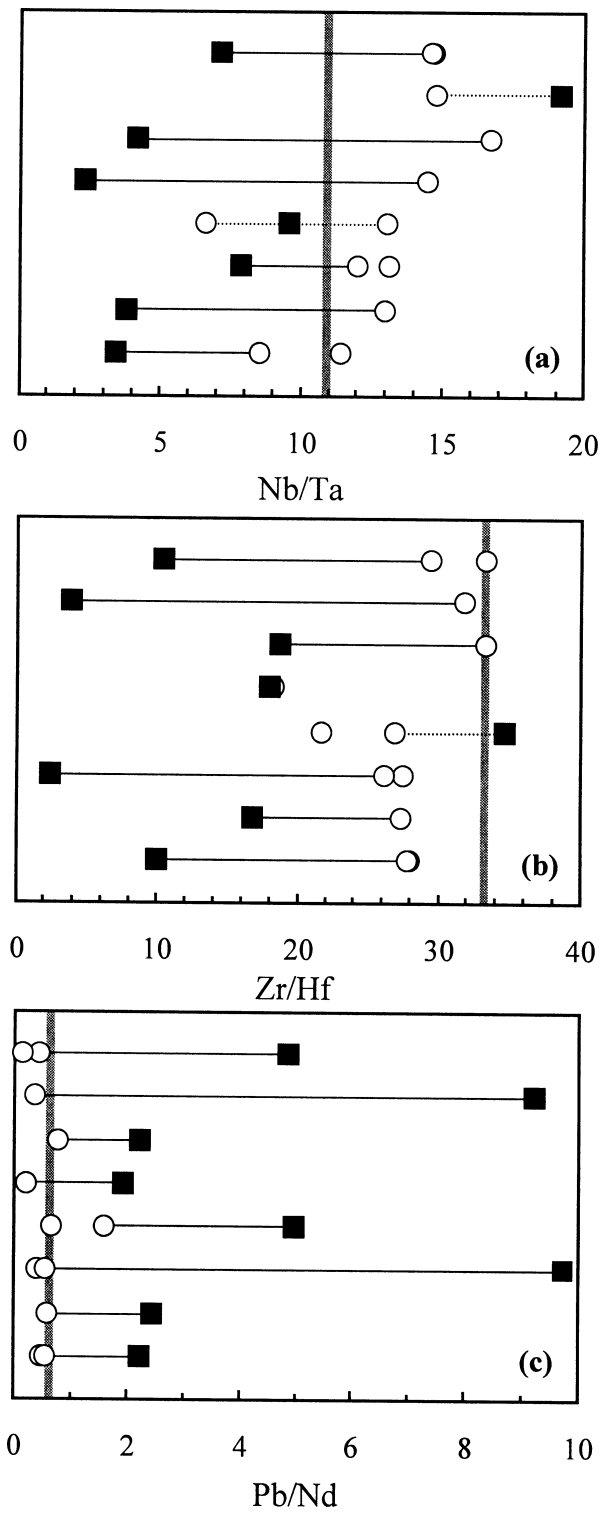

Fig. 7. $\mathrm{Nb} / \mathrm{Ta}(\mathrm{a}), \mathrm{Zr} / \mathrm{Hf}(\mathrm{b})$ and $\mathrm{Pb} / \mathrm{Nd}(\mathrm{c})$ ratios of the veins (solid squares) and their immediate wallrocks (open circles) of the Xingzi Group. The shaded perpendicular lines in (a) to (c) indicate the corresponding ratios of the continental crust from Rudnick (1995). See text for explanations.

Compared to their wallrocks, most of the metamorphic veins have obviously lower $\mathrm{Nb} / \mathrm{Ta}$ and $\mathrm{Zr} / \mathrm{Hf}$ ratios (Figs. $7 \mathrm{a}$ and $7 \mathrm{~b}$ ). The $\mathrm{Nb} / \mathrm{Ta}$ and $\mathrm{Zr} /$ Hf ratios of the wallrocks are very close to those of the continental crust estimated by Rudnick 
(1995), but the corresponding ratios of the veins are generally lower than those of the continental crust (Figs. $7 \mathrm{a}$ and $7 \mathrm{~b}$ ). The $\mathrm{Zr} / \mathrm{Hf}$ ratios of the veins are also away from the CHARAC (CHArgeand-RAdius-Controlled) field ( $26<\mathrm{Zr} / \mathrm{Hf}<46$, $\mathrm{Bau}, 1996)$. Although these lower ratios of $\mathrm{Nb} / \mathrm{Ta}$ and $\mathrm{Zr} / \mathrm{Hf}$ in the veins might be analytical artifacts, especially so for the quartz veins due to their very low abundances of most trace elements, the careful sample preparation and successful analytical procedure (Qi et al., 2000; Qi and Grégoire, 2000) exclude this possibility. The trace element abundances of the quartz veins were analyzed when they were concentrated by 5, 10 and/or 25 times, which makes the abundances in the solutions larger by several orders of magnitude than the detection limits of these elements, and the analytical results for the same sample are consistent with each other within error limits. Consequently, we argue that these consistent characteristics resulted from fractionation of these trace elements, which is strongly influenced by electron configuration and the nature of complexing ligands of aqueous fluids (Bau, 1996). In the data of Henry et al. (1996), the fractionations of $\mathrm{Nb}-\mathrm{Ta}$ and $\mathrm{Lu}-$ Hf are also apparent (Kamber and Collerson, 2000). Another geochemical pair, $\mathrm{Pb}$ and $\mathrm{Nd}$ with the similar incompatibility and generally no significant fractionation in silicate-melt systems, is fractionated during metamorphic dehydration. It is clearly shown in Fig. 7c that the veins invariably have much higher $\mathrm{Pb} / \mathrm{Nd}$ ratios than their wallrocks, which coherently have the same values as the continental crust. The fractionation of these geochemical pairs suggest that bulk partition coefficients of $\mathrm{Ta}$, $\mathrm{Hf}$ and $\mathrm{Pb}$ between fluid and rock ( $\left.D^{\text {fluid/rock }}\right)$ are generally higher than those of $\mathrm{Nb}, \mathrm{Zr}$ and $\mathrm{Nd}$, respectively. Table 3 shows that the felsic veins at Huangyansi have higher concentrations of Ta than their wallrocks. Although the mechanism for this is not clear by far, however, one possibility is that the element in the case of Huangyansi is not so immobile as generally regarded, and the Ta in these veins was possibly derived from large amounts of wallrocks. The fractionation between $\mathrm{Y}$ and Ho, which as one of geochemical pairs with identical charge $\left(3^{+}\right)$and similar ionic radius (1.019 $\AA$ for $\mathrm{Y}^{3+}$ and $1.015 \AA$ for $\mathrm{Ho}^{3+}$ in VI coordination; Shannon, 1976), has been shown in several environments where the REE tetrad effect also exists (e.g., Bau, 1996; Irber, 1999), and proposed as an indicator of trace element behaviour in aqueous systems (Bau, 1996). Most of the studied veins (especially the quartz ones), along with all the wallrocks, have Y/Ho ratios nearly comparable to chondritic value (Table 3). In contrast, the wholerock of felsic vein sample 34-4 and its garnet separate have Y/Ho ratios of 42 and 39, respectively, markedly higher than that of chondrite. These non-chondritic Y/ Ho ratios further imply that this geochemical pair was fractionated during metamorphic dehydration and the felsic veins were also formed in a fluidrich environment. Several studies suggest that fluorine complexation in fluids may closely be related to the REE tetrad effect and the fractionation of some of the geochemical pairs (Bau and Dulski, 1995; Bau, 1996; Irber, 1999), however, fractionation of trace elements also occur in many other cases without or depleted fluorine (Liu et al., 1993; Akagi et al., 1993; Minami et al., 1998). By comparing the trace element compositions in the rocks from a prograde metamorphic terrain (the Catalina Schist) in a subductionzone, Bebout et al. (1999) have demonstrated that metamorphic fluids had highly fractionated trace element compositions. From these case studies, it can be inferred that fractionation of trace elements is most likely a commonly occurring process during metamorphic dehydration. Considering the various geochemical fractionations observed in this study (Nb-Ta, Zr-Hf, and Pb-Nd) and in Henry et al. (1996) ( $\mathrm{Nb}-\mathrm{Ta}$ and $\mathrm{Lu}-\mathrm{Hf})$, we therefore infer that the fractionation of trace elements is mainly controlled by the chemical nature of fluids (closely related to protolith chemistry) and metamorphic conditions. From this consideration, the fact that no the REE tetrad effect is observed in the quartz veins at Xixiansi (Fig. 2a) can probably be attributed to a compositional difference between the metamorphic fluids from Xixiansi and from Huangyansi, although the compositions of 
these metamorphic fluids have not been precisely determined.

The large ion lithophile elements, which tend to concentrate equally in upper continental rocks during mantle/crust evolution due to their similar mineral/melt partition coefficients, show varying behaviour during metamorphic dehydration. La/ $\mathrm{Ba}, \mathrm{Sr} / \mathrm{Nd}$ and $\mathrm{Th} / \mathrm{Hf}$ ratios are identical and show a limited variation among the veins and their wallrocks. $\mathrm{Rb} / \mathrm{Ba}, \mathrm{Ba} / \mathrm{Nb}$ and $\mathrm{La} / \mathrm{Nb}$ ratios are similar in the quartz veins and all the wallrocks, but are mostly different in the felsic veins. This further suggests a control of the chemical composition of the fluids over the fractionation of trace elements.

\section{REE mobility and its controlling factors}

Previous studies on the controversial issue of REE mobility during metamorphism indicate that REEs are (1) immobile (e.g., Bernard-Griffiths et al., 1985), (2) coherently mobile (e.g., Hellman et al., 1979; Nyström, 1984), and (3) selectively mobile, including LREE mobility (Wood et al., 1976; Wear and Tarney, 1981) or HREE mobility (Stahle et al., 1987). These studies show that the behaviour of the REEs during metamorphism are very complex, and that the REEs are mobile under some circumstances and are immobile under other circumstances (Grauch, 1989).

In the Xingzi Group metasedimentary rocks, metamorphic fluids, principally $\mathrm{H}_{2} \mathrm{O}$ and $\mathrm{CO}_{2}$, were produced by devolatilization reactions and released from the wallrocks during regional metamorphism. Accompanied with the production and migration of the fluids, major elements $\mathrm{K}, \mathrm{Na}, \mathrm{Si}$, and $\mathrm{Al}$ were reactivated and transported, which is clearly indicated by the occurrences of quartz, feldspar in the quartz and felsic veins. The REEs are also obviously mobilized during this process, as can be inferred from the fact that all the veins contain some amount of the REEs (up to $47 \mathrm{ppm}$ ). According to the variations of the chondrite-normalized patterns between the veins and their wallrocks (Fig. 2), the signatures of REE mobility at the investigated locations are significantly different from each other. At Xixiansi, the similar
REE patterns between the veins and their immediate wallrocks suggest coherent REE mobility. However, the REEs are selectively mobile (favoring HREE mobility) at Huangyansi, as indicated by relatively high HREE abundances in the veins (Table 3, Fig. 2b). Because the geological setting and metamorphic conditions are identical, the different characteristics of REE mobility should be attributed to the difference in mineral compositions of protoliths at each location. Due to more clay minerals in the protolith at Huangyansi, larger amounts of fluids with higher $\mathrm{CO}_{2}$ contents were produced than at Xixiansi during metamorphic dehydration. The HREEs in the protolith at Huangyansi are more easily mobilized into and transported by the metamorphic fluid, as suggested by Stahle et al. (1987) and the study of Bau (1991). This further indicates that REE behaviour (including their mobility) during metamorphism is mainly controlled by the chemical composition of the metamorphic fluid, which, in turn, depends on the mineralogical composition of the protoliths.

\section{SUMMARY}

Field occurrences and comparative studies of trace element and oxygen isotopic compositions of the veins and their wallrocks in the Xingzi Group reveal that the veins studied are synmetamorphic in origin and were deposited by fluids. The estimated oxygen isotopic composition of the metamorphic fluid at Xixiansi is markedly different from that at Huangyansi, indicating that there was no pervasive fluid infiltration on a relatively large scale during amphibolite facies metamorphism of the Xingzi Group.

The quartz veins at Xixiansi have REE patterns that are smooth and extremely similar to their wallrocks. In contrast, the veins and their garnet separates at Huangyansi have irregular REE patterns (the REE tetrad effect). The $\mathrm{Nb} / \mathrm{Ta}, \mathrm{Zr} / \mathrm{Hf}$ and $\mathrm{Pb} / \mathrm{Nd}$ ratios in the veins are much different from those in their wallrocks. Trace element ratios, such as $\mathrm{La} / \mathrm{Ba}, \mathrm{Sr} / \mathrm{Nd}$, Th/Hf, are similar in all the veins and the wallrocks. Ratios of $\mathrm{Rb} / \mathrm{Ba}$, 
$\mathrm{Ba} / \mathrm{Nb}$ and $\mathrm{La} / \mathrm{Nb}$ are similar in the quartz veins and all the wallrocks, but different in the felsic veins. These variable geochemical signatures further suggest that variable REE and trace element mobility is related to the composition of the fluids that precipitated the veins.

The various REE abundances in the veins show that the REEs in the Xingzi group sedimentary rocks can be mobilized to some extent by the complexation of the REEs with metamorphic fluids under the conditions of amphibolite facies metamorphism. The REE mobility at Huangyansi is quite different from that at Xixiansi because of the difference in mineralogical composition of the protoliths (pelitic vs. psammitic). Consequently, the mineralogical compositions of the protoliths do play an important role in controlling those of the fluids and geochemical behaviour of the REEs and other trace elements during metamorphism.

Acknowledgments-Many thanks are due to Dr. Balz Kamber, Dr. Michael Bau, and Prof. Christian Koeberl for their valuable reviews and patience in revising the English of this paper. We greatly appreciate the constructive comments on an earlier version of this manuscript by Prof. Alan Matthews. The help in major and trace element analyses by Sun-rong Li and Liang Qi, respectively, and in field trip by Guo-gang Xie are gratefully acknowledged. This research was supported by National Science Foundation of China under the National Outstanding Young Scientist Foundation Project (Grant 49625304), Ministry of Science and Technology of China under National Climbing Project No. 95-P-39, and Advanced Field Program under KIP of CAS (Grant 200208 of IGCAS).

\section{REFERENCES}

Ague, J. J. (1991) Evidence for major mass transfer and volume strain during regional metamorphism of pelites. Geology 19, 855-858.

Ague, J. J. (1994) Mass transfer during Barrovian metamorphism of pelites, south-central Connecticut. II: Channelized fluid flow and the growth of staurolite and kyanite. Am. J. Sci. 294, 1061-1134.

Akagi, T., Shabani, M. B. and Masuda, A. (1993) Lanthanide tetrad effect in kimuraite $\left[\mathrm{CaY}_{2}\left(\mathrm{CO}_{3}\right)_{4} \cdot 6 \mathrm{H}_{2} \mathrm{O}\right]$ : Implication for a new geochemical index. Geochim. Cosmochim. Acta 57, 2899-2905.
Anders, E. and Grevesse, N. (1989) Abundances of the elements: Meteoritic and solar. Geochim. Cosmochim. Acta 53, 197-214.

Anderson, G. M. and Burnham, C. W. (1983) Feldspar solubility and the transport of aluminum under metamorphic conditions. Am. J. Sci. 283-A, 283-297.

Bau, M. (1991) Rare-earth element mobility during hydrothermal and metamorphic fluid-rock interaction and the significance of the oxidation state of europium. Chem. Geol. 93, 219-230.

Bau, M. (1996) Controls on the fractionation of isovalent trace elements in magmatic and aqueous systems: evidence from $\mathrm{Y} / \mathrm{Ho}, \mathrm{Zr} / \mathrm{Hf}$, and lanthanide tetrad effect. Contrib. Mineral. Petrol. 123, 323-333.

Bau, M. (1997) The lanthanide tetrad effect in highly evolved felsic igneous rocks-a reply to the comment by Y. Pan. Contrib. Mineral. Petrol. 128, 409412.

Bau, M. and Dulski, P. (1995) Comparative study of yttrium and rare-earth element behaviours in fluorine-rich hydrothermal fluids. Contrib. Mineral. Petrol. 119, 213-223.

Bebout, G. E. and Barton, M. (1989) Fluid flow and metamorphism in a subduction zone hydrothermal system: Catalina Schist terrane, California. Geology 17, 976-980.

Bebout, G. E., Ryan, J. G. and Leeman, W. P. (1999) Fractionation of trace elements by subduction-zone metamorphism-effect of convergent-margin thermal evolution. Earth Planet. Sci. Lett. 171, 63-81.

Becker, H., Jochum, K. P. and Carlson, R. W. (1999) Constraints from high-pressure veins in eclogites on the composition of hydrous fluids in subduction zones. Chem. Geol. 160, 291-308.

Bernard-Griffiths, J., Peucat, J.-J., Iglesias Ponce de Leon, M. and Gil Ibarguchi, J. I. (1985) U-Pb, Nd isotope and REE geochemistry in eclogites from the Cabo Ortegal Complex, Galicia, Spain: an example of REE immobility conserving MORB-like patterns during high-grade metamorphism. Chem. Geol. 52, 217-225.

Cartwright, I., Oliver, W. L., Oliver, N. H. S., Valenta, R. K. and McLatchie, G. S. (1994) Fluid migration and vein formation during deformation and greenschist facies metamorphism at Ormiston Gorge, central Australia. J. Metamorph. Geol. 12, 373-386.

Cesare, B. (1994) Synmetamorphic veining: origin of andalusite-bearing veins in the Vedrette di Ries contact aureole, Eastern Alps, Italy. J. Metamorph. Geol. 12, 643-653.

Chen, J.-F., Foland, K. A., Xing, F.-M., Xu, X. and Zhou, T.-X. (1991) Magmatism along the southeast margin of the Yangtze block: Precambrian collision of the Yangtze and Cathysia blocks of China. Geol- 
ogy 19, 815-818.

Clayton, R. N. and Mayeda, T. K. (1963) The use of bromine pentafluoride in the extraction of oxygen from oxides and silicates for isotopic analysis. Geochim. Cosmochim. Acta 27, 43-52.

Ferry, J. M. (1983) Mineral reactions and element migration during metamorphism of calcareous sediments from the Vassalboro Formation, south-central Maine. Am. Mineral. 68, 334-354.

Garlick, G. D. and Epstein, S. (1967) Oxygen isotope ratios in coexisting minerals of regionally metamorphosed rocks. Geochim. Cosmochim. Acta 31, 181214.

Grauch, R. I. (1989) Rare earth elements in metamorphic rocks. Rev. Mineral. 21, 147-167.

Haas, J. R., Shock, E. L. and Sassani, D. C. (1995) Rare earth elements in hydrothermal systems: Estimates of standard partial molal thermodynamic properties of aqueous complexes of the rare earth elements at high pressures and temperatures. Geochim. Cosmochim. Acta 59, 4329-4350.

Hellman, P. L., Smith, R. E. and Henderson, P. (1979) The mobility of the rare earth elements: Evidence and implications from selected terrains affected by burial metamorphism. Contrib. Mineral. Petrol. 71, 23-44.

Henry, C., Burkhard, M. and GoffÈ, B. (1996) Evolution of synmetamorphic veins and their wallrocks through a Western Alps transect: no evidence for large-scale fluid flow. Stable isotope, major- and trace-element systematics. Chem. Geol. 127, 81-109.

Hidaka, H., Holliger, P., Shimizu, H. and Masuda, A. (1992) Lanthanide tetrad effect observed in the Oklo and ordinary uraninites and its implication for their forming processes. Geochem. J. 26, 337-346.

Irber, W. (1999) The lanthanide tetrad effect and its correlation with $\mathrm{K} / \mathrm{Rb}, \mathrm{Eu} / \mathrm{Eu}^{*}, \mathrm{Sr} / \mathrm{Eu}, \mathrm{Y} / \mathrm{Ho}$, and $\mathrm{Zr} /$ Hf of evolving peraluminous granite suites. Geochim. Cosmochim. Acta 63, 489-508.

Javoy, M. (1977) Stable isotopes and geothermometry. J. Geol. Soc. London 133, 609-636.

Jolliff, B. L., Papike, J. J., Shearer C. K. and Shimizu, N. (1989) Inter- and intra-crystal REE variations in apatite from the Bob Ingersoll pegmatite, Black Hills, South Dakota. Geochim. Cosmochim. Acta 53, 429441.

Kamber, B. S. and Collerson, K. D. (2000) Role of 'hidden' deeply subducted slabs in mantle depletion. Chem. Geol. 166, 241-254.

Kawabe, I., Kitahara, Y. and Naito, K. (1991) Nonchondritic yttrium/holmium ratio and lanthanide tetrad effect observed in pre-Cenozoic limestones. Geochem. J. 25, 31-44.

Lee, S.-G., Masuda, A. and Kim, H.-S. (1994) An early
Proterozoic leuco-granitic gneiss with the REE tetrad phenomenon. Chem. Geol. 114, 59-67.

Li, W.-X., Xu, X.-S., Zhou, X.-M., Xie, G.-G., Li, J.-H. and Li, H.-M. (1998) Epidote granite in the 'Xingzi Complex' of Lushan Mountain: Dating and genesis. Geological Review 44, 143-148 (in Chinese with English abstract).

Liu, C.-Q., Masuda, A., Okada, A., Yabuki, S., Zhang, J. and Fan, Z.-L. (1993) A geochemical study of loess and desert sand in northern China: Implications for continental crust weathering and composition. Chem. Geol. 106, 359-374.

Masuda, A. and Akagi, T. (1989) Lanthanide tetrad effect observed in leucogranites from China. Geochem. J. 23, 245-253.

Masuda, A. and Ikeuchi, Y. (1979) Lanthanide tetrad effect observed in marine environment. Geochem. J. 13, 19-22.

McLennan, S. M. (1994) Rare earth element geochemistry and the "tetrad" effect. Geochim. Cosmochim. Acta 58, 2025-2033.

Minami, M., Masuda, A., Takahashi, K., Adachi, M. and Shimizu, H. (1998) Y-Ho fractionation and lanthanide tetrad effect observed in cherts. Geochem. J. 32, 405-419.

Nichols, G. T., Wyllie, P. J. and Stern, C. R. (1994) Subduction zone melting of pelagic sediments constrained by melting experiments. Nature 371, 785788.

Nyström, J. O. (1984) Rare earth element mobility in vesicular lava during low-grade metamorphism. Contrib. Mineral. Petrol. 88, 328-331.

Pan, Y. (1997) Controls on the fractionation of isovalent trace elements in magmatic and aqueous systems: evidence from $\mathrm{Y} / \mathrm{Ho}, \mathrm{Zr} / \mathrm{Hf}$, and lanthanide tetrad effect-a discussion of the article by M. Bau (1996). Contrib. Mineral. Petrol. 128, 405-408.

Peng, Z.-R., Wu, X.-H. and Han, Z.-R. (1995) The features of the microflora in Shuangqiaoshan Group in the Dagang area, Duchang county, Jiangxi province. Regional Geology of China 14, 131-134 (in Chinese with English abstract).

Peppard, D. F., Mason, G. W. and Lewey, S. (1969) A tetrad effect in the liquid-liquid extraction ordering of lanthanide (III). J. Inorg. Nucl. Chem. 31, 339343.

Putlitz, B., Valley, J. W., Matthews, A. and Katzir, Y. (2002) Oxygen isotope thermometry of quartz$\mathrm{Al}_{2} \mathrm{SiO}_{5}$ veins in high-grade metamorphic rocks on Naxos island (Greece). Contrib. Mineral. Petrol. 143, 350-359.

Qi, L. and Grégoire, D. C. (2000) Determination of trace elements in twenty-six Chinese materials by inductively coupled plasma-mass spectrometry. Geostand. 
Newslett. 24, 51-63.

Qi, L., Hu, J. and Grégoire, D. C. (2000) Determination of trace elements in granites by inductively coupled plasma mass spectrometry. Talanta 51, 507-513.

Rudnick, R. L. (1995) Making continental crust. Nature 378, 571-578.

Shannon, R. D. (1976) Revised effective ionic radii and systematic studies of interatomic distances in halides and chalcogenides. Acta Cryst. A32, 751-767.

Smith, M. P. and Yardley, B. W. D. (1999) Fluid evolution during metamorphism of the Otago Schist, New Zealand: (1) Evidence from fluid inclusions. $J$. Metamorph. Geol. 17, 173-186.

Stahle, H. J., Raith, M., Hoernes, S. and Delfs, A. (1987) Element mobility during incipient granulite formation at Kabbaldurga, southern India. J. Petrol. 28, 803-834.

Sun, S. S. and McDonough, W. F. (1989) Chemical and isotopic systematics of oceanic basalts: implications for mantle composition and processes. Magmatism in the Ocean Basins (Saunders, A. D. and Norry, M. J., eds.), 313-345, Geological Society Special Publication No. 42.

Tang, H.-F., Liu, C.-Q. and Ni, P. (2000) Inclusion study on metamorphic fluids from the Xingzi Group, Lushan. Acta Miner. Sinica 20, 286-292 (in Chinese with English abstract).

van Haren, J. L. M., Auge, J. J. and Rye, D. M. (1996) Oxygen isotope record of fluid infiltration and mass transfer during regional metamorphism of pelitic schist, Connecticut, USA. Geochim. Cosmochim. Acta 60, 3487-3504.

Vidale, R. J. (1974) Vein assemblages and metamorphism in Dutchess County, New York. Geol. Soc. Am. Bull. 85, 303-306.

Wang, K.-Y., Cheng, H. and Ye, Y. (1992) The Xingzi complex: Primary studies of its metamorphic P-T conditions and tectonic setting. Studies on the Construction and Evolution of the Oceanic and Continental Lithospheres in Southeastern China (Li, J.-L., ed.), 133-139, Science and Technology Publishing House of China, Beijing (in Chinese).

Wear, B. L. and Tarney, J. (1981) Chemical changes during dyke metamorphism in high-grade basement terrains. Nature 289, 47-49.

Wilkinson, J. J., Nolan, J. and Rankin, A. H. (1996) Silicothermal fluid: A novel medium for mass transport in the lithosphere. Geology 24, 1059-1062.

Wood, D. A., Gibson, I. L. and Thompson, R. N. (1976) Element mobility during zeolite facies metamorphism of the Tertiary basalts of eastern Iceland. Contrib. Mineral. Petrol. 55, 241-254.

Wood, S. A. (1990) The aqueous geochemistry of the rare-earth elements and yttrium, 1. Review of available low-temperature data for inorganic complexes and the inorganic REE speciation of natural waters. Chem. Geol. 82, 159-186.

Xie, G.-G. (1997) On the lower boundary of the Shuangqiaoshan Group in Jiangxi. Regional Geology of China 16, 410-414 (in Chinese with English abstract).

Xie, G.-G., Li, J.-H., Li, W.-X., Tang, H.-F., Li, H.-M. and Zhou, X.-M. (1997) Zircon U-Pb dating of Presinian rocks at Lushan MT. and its geological implication. Scientia Geologica Sinica 32, 110-115 (in Chinese with English abstract).

Yardley, B. W. D. (1975) On some quartz-plagioclase veins in the Connemara Schists. Geol. Mag. 112, 183190.

Yardley, B. W. D. (1983) Quartz veins and devolatilization during metamorphism. J. Geol. Soc. London 140, 657-663.

Yardley, B. W. D. (1986) Fluid migration and veining in the Connemara Schists, Ireland. Fluid-Rock Interactions During Metamorphism (Walther, J. V. and Wood, B. J., eds.), 109-131, Springer-Verlag, New York.

Yardley, B. W. D. and Bottrell, S. H. (1992) Silica mobility and fluid movement during metamorphism of the Connemara schists, Ireland. J. Metamorph. Geol. 10, 453-464.

Zhao, J.-X. and Copper, J. (1992) Fractionation of monazite in the development of V-shaped REE patterns in leucogranite system: evidence from a muscovite body in central Australia. Lithos 30, 23-32. 